Note

\section{Participation of the Hydrophobic Bond in Complex Formation between $\kappa$-Casein and $\beta$-Lactoglobulin}

\author{
Hiroshi DoI, Shoji IDENo, \\ Fumio IBUKI and Masao KANAMORI \\ Department of Agricultural Chemistry, \\ Kyoto Prefectural University, \\ Shimogamo, Kyoto 606, Japan
}

Received June 10, 1982

It is well known that $\kappa$-casein plays an important role in stabilizing casein micelles, ${ }^{1}$ and forms a heat-induced complex with $\beta$-lactoglobulin which is one of the main components of whey proteins. ${ }^{2,3)}$ This $\kappa$-casein- $\beta$ lactoglobulin interaction is of considerable importance in determining the heat stability and rennin clottability of milk and some of its products. ${ }^{4,5)}$ It has been suggested that sulfhydryl groups are involved in the reaction of $\beta$ lactoglobulin with $\kappa$-casein, ${ }^{6,7)}$ and most of the available evidence points to such an - $\mathrm{SH} /-\mathrm{S}-\mathrm{S}$ - interchange as the principal reaction mechanism. However, the exact mechanism of this interaction still has not been explained, and further studies are required for its clarification. ${ }^{8,9)}$

In our laboratory, $\kappa$-casein has been fractionated by carbohydrate content, ${ }^{10)}$ and the interaction between each $\kappa$-casein component and $\beta$-lactoglobulin has been examined. ${ }^{11,12)}$ Our earlier results indicated that the carbohydrate moiety played an integral part in the interaction, and, therefore, that some additional reaction mechanism was involved in addition to the $-\mathrm{SH} /-\mathrm{S}-\mathrm{S}$ - interchange. In order to clarify this interaction, we followed the changes in ultraviolet and fluorescence emission spectra observed during complex formation.

Bovine $\kappa$-casein was prepared from the milk of an individual Holstein cow, and the $\kappa$-casein components were fractionated by diethylaminoethyl-cellulose chromatography. ${ }^{10)} \beta$-Lactoglobulin was purchased from Sigma Chemical Co. The buffer used was a $10 \mathrm{~mm}$ imidazole- $\mathrm{HCl}$ buffer, $\mathrm{pH} 7.1$, containing $70 \mathrm{~mm} \mathrm{KCl}$ (called the standard buffer). Ultraviolet absorption spectra were obtained using a Hitachi dual wavelength-double beam spectrophotometer, Model 557, and fluorescence measurements were made with a Shimadzu fluorescence spectrophotometer, Model RF-502. $\beta$-Lactoglobulin and $\kappa$-casein were heated at $75^{\circ} \mathrm{C}$ for $20 \mathrm{~min}$. The protein concentration of the reaction mixture was $1 \mathrm{mg} / \mathrm{ml}$. Complex formation was confirmed by gel filtration on Sephacryl S-300 using the standard buffer containing $4.6 \mathrm{M}$ urea. ${ }^{12)}$ Acetylation of

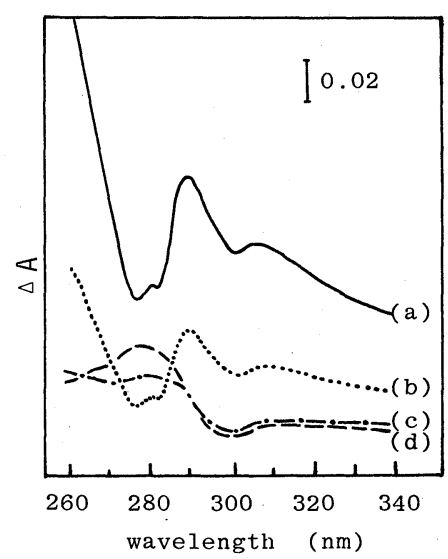

FIG. 1. Comparison of the Difference Spectra of Unheated and Heated Proteins.

Two cells of identical pathlength were filled with solutions containing $2 \mathrm{mg} / \mathrm{ml}$ protein. The sample, having at least one heated protein, was measured versus a reference mixture containing only unheated proteins. (a) both native proteins; (b) native $\kappa$-casein and modified $\beta$-lactoglobulin; (c) modified $\kappa$-casein and native $\beta$-lactoglobulin; (d) both modified proteins.

the tyrosine residue was carried out according to the method of Riordan et al. ${ }^{13)}$ and the degree of acetylation was determined by measuring the decrease in absorbance at $278 \mathrm{~nm} .{ }^{14)}$ The amounts of modifiable tyrosine present in $\kappa$-casein and $\beta$-lactoglobulin were 80 and $30 \%$, respectively.

When $\kappa$-casein or $\beta$-lactoglobulin was heated alone, there was no change in the ultraviolet spectrum. However, a change was induced by heating a mixture of both proteins, and a peak at $288 \mathrm{~nm}$ appeared in the difference spectrum of the heated and unheated mixtures (Fig. 1(a)). The absorption spectrum of the unheated mixture of the two proteins indicates a peak at $276 \mathrm{~nm}$, so it can be interpreted from the difference spectrum that the red shift of the absorption spectrum occurred as a result of the heat treatment. This fact implies a change in the environment of the chromophore, namely tyrosine, phenylalanine or tryptophan, which, in turn, results in complex formation. So we examined what changes occurred in each of the chromophores by acetylating the tyrosine residues of $\kappa$ casein and $\beta$-lactoglobulin. The peak at $288 \mathrm{~nm}$ nearly disappeared from the difference spectra of heated mixtures of modified $\kappa$-casein with native or modified $\beta$-lactoglobulin (Fig. 1(c) or (d)). With a mixture of modified $\beta$ lactoglobulin and unmodified $\kappa$-casein, the $288 \mathrm{~nm}$ peak of difference spectrum became much smaller than that obtained for the mixture of native proteins (Fig. 1(b)). These results indicated that the change in ultraviolet spectrum resulting from the complex formation was due to a change in the environment of the tyrosine residue. Tyrosine 


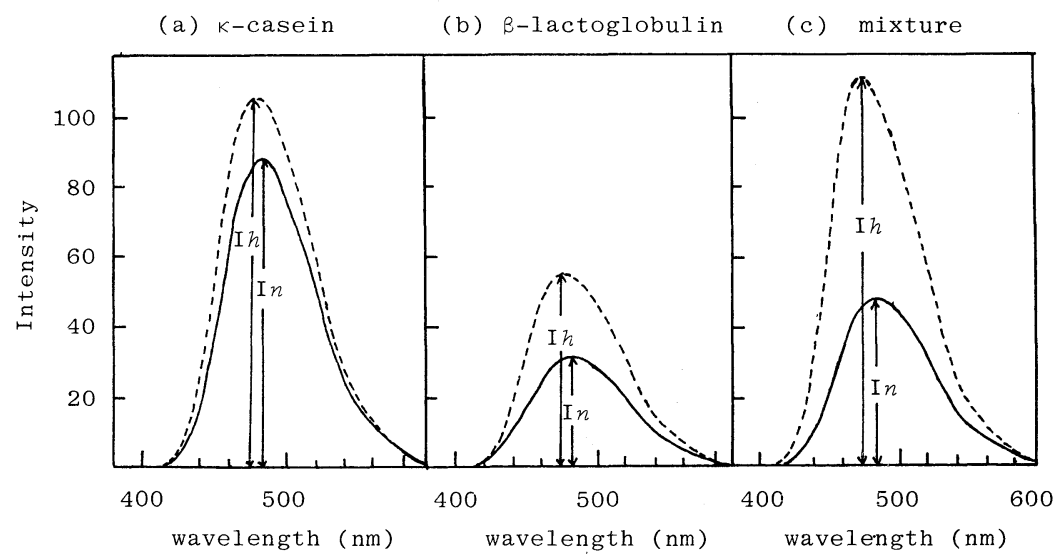

FIG. 2. The Fluorescence Emission Spectra of ANS Bound to Heated and Unheated Proteins.

The fluorescence spectra of the protein solutions (in $10 \mathrm{~mm}$ imidazole- $\mathrm{HCl}$ buffer, $\mathrm{pH} 7.1$, containing $70 \mathrm{~mm}$ $\mathrm{KCl}$ ) were taken in the presence of $0.1 \mathrm{mM}$ ANS at $25^{\circ} \mathrm{C}$. The protein concentration was $0.1 \mathrm{mg} / \mathrm{ml}$, and the activation wavelength was $374 \mathrm{~nm}$. - unheated; ----, heated at $75^{\circ} \mathrm{C}$ for $20 \mathrm{~min}$.

absorption is dependent on the polarity of its environment or on $\mathrm{pH}$. Ionization of the phenol moiety or a decrease in polarity around the tyrosine molecule increases the extinction and shifts the absorption bands to longer wavelengths. When the charge on the tyrosine residue changes, the peaks at 295 and $243 \sim 245 \mathrm{~nm}$ appear. On the other hand, the peaks at 286, 279 and near $230 \mathrm{~nm}$ in the difference spectrum appear when the polarity of the environment changes. ${ }^{15)}$ Therefore, it is postulated that the decrease in polarity surrounding the tyrosine residues was a major factor in the change of absorption spectrum resulting from complex formation. All of the tyrosine residues of $\kappa$-casein are situated in para- $\kappa$ casein. Furthermore, the primary structure of bovine $\beta$-lactoglobulin indicates all of its tyrosine residues are located in the hydrophobic region of the molecule. Therefore, it was interpreted that the decrease in the polarity around the tyrosine residues, which resulted in complex formation, was attributed to the binding of the hydrophobic regions of both proteins. To prove the existence of this hydrophobic bond the fluorescence spectra of heated and unheated mixtures of the two proteins were examined. 1-Anilino-8-naphtalenesulfonate (ANS) was used as a probe for locating the hydrophobic regions. Both the quantum yield of fluorescence and the maximum emission wavelength of the ANS bound to protein are dependent on the polarity of the binding region - the lower polarity of the ANS-binding region is, the larger the intensity and the shorter the wavelength of the emission maximum. ${ }^{16)}$ When either $\kappa$-casein or $\beta$-lactoglobulin was heated alone, the fluorescence intensity increased, and the wavelength of the emission maximum became shorter (Fig. 2(a) and (b)). However, when the mixture was heated, the increase of the fluorescence intensity and the shift of the emission maximum to a

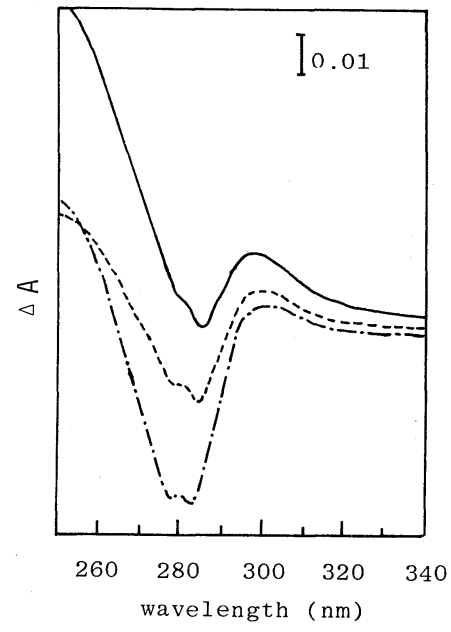

FIG. 3. Difference Spectra of the $\kappa$-Casein Components.

Two identical cells were filled with solutions having a protein concentration of $0.4 \mathrm{mg} / \mathrm{ml}$. The sample cell, filled with a single $\kappa$-casein component, was measured against a reference cell containing unfractionated $\kappa$-casein. component P-2; ----, component P-4; -- -, component P-6.

shorter wavelength were even more remarkable (Fig. 2(c)). These facts indicated the presence of a hydrophobic bond between the two proteins, a result of complex formation. Thus, the data obtained for both the ultraviolet and fluorescence determinations indicated the same conclusion.

The ultraviolet difference spectra of the $\kappa$-casein components were measured against a reference solution of unfractionated $\kappa$-casein (Fig. 3). The absorption shifts in 
the blue region of the spectrum observed for components P-4 and P-6, which contain carbohydrate residues, were larger than that for the P-2 component having no sugar. From these facts, it was concluded that the hydrophobic regions of components P-4 and P-6 were exposed to solvent while to that of component P-2 was not. ${ }^{15)}$ Thus, it was postulated that the conformation of the $\kappa$-casein component containing carbohydrates was favorable for formation of a hydrophobic bond with $\beta$-lactoglobulin. Hill and Wake have suggested that the $\alpha_{\mathrm{sl}}-\kappa$-casein interaction is significantly hydrophobic in nature. ${ }^{17)}$ The difference spectrum for $\alpha_{\mathrm{sl}}-\kappa$-casein complex formation is similar to that obtained for the $\kappa$-casein- $\beta$-lactoglobulin complex in our laboratory.

These results support the existence of the hydrophobic bond in the heat-induced $\kappa$-casein- $\beta$-lactoglobulin complex. However, the $288 \mathrm{~nm}$ peak in the difference spectrum is decreased by reduction of the complex with 2-mercaptoethanol. Therefore, the formation of a complex between $\beta$-lactoglobulin and S-carboxymethylated $\kappa$-casein, prepared by the method of Crestifield et al. ${ }^{18)}$ was examined by gel filtration. It was found that the S-carboxymethylated $\kappa$-casein did not form a complex with $\beta$-lactoglobulin. Thus, it was concluded that the $\kappa$-casein $/ \beta$-lactoglobulin interaction is due to an $-\mathrm{SH} /-\mathrm{S}-\mathrm{S}$ - interchange between the two proteins as well as to the hydrophobic bond formation.

\section{REFERENCES}

1) A. G. Mackinlay and R. G. Wake, "Milk Proteins," Vol. II, ed. by H. A. McKenzie, Academic Press, New York, 1971, pp. 175 215.

2) J. Tobias, R. M. Whitney and P. H. Tracy, J. Dairy
Sci., 35, 1036 (1952).

3) W. L. Slatter and Q. van Winkle, J. Dairy Sci., 35, 1083 (1952).

4) A. Kannan and R. Jénness, J. Dairy Sci., 44, 808 (1961).

5) C. V. Morr and R. V. Josephson, J. Dairy Sci., 51, 1349 (1968).

6) W. H. Sawyer, S. T. Coulter and R. Jenness, J. Dairy Sci., 46, 564 (1963).

7) R. Parkayastha, H. Tessier and D. Rose, J. Dairy Sci., 50, 764 (1967).

8) W. J. Harper, J. Dairy Sci., 64, 1028 (1981).

9) J. R. Brunner, J. Dairy Sci., 64, 1038 (1981).

10) H. Doi, F. Ibuki and M. Kanamori, J. Dairy Sci., 62, 195 (1979)

11) H. Doi, F. Ibuki and M. Kanamori, Agric. Biol. Chem., 45, 2351 (1981).

12) H. Doi, S. Ideno, F. Ibuki and M. Kanamori, Eiyo to Shokuryo, 34, 565 (1981).

13) J. F. Riordan, W. E. C. Wacker and B. L. Vallee, Biochemistry, 4, 1758 (1965).

14) R. T. Simpson, J. F. Riordan and B. L. Vallee, Biochemistry, 2, 616 (1963).

15) K. Hayashi and T. Imoto, "Protein Chemistry," Vol. III, ed. by Japanese Biochemical Society, Tokyo Kagaku Dojin, Tokyo, 1976, pp. 118 143.

16) T. Sekine, T. Ohyashiki and H. Kokubun, "Protein Chemistry," Vol. III, ed. by Japanese Biochemical Society, Tokyo Kagaku Dojin, Tokyo, 1976, pp. $199 \sim 240$.

17) R. D. Hill and R. G. Wake, Nature, 221, 635 (1969).

18) A. M. Crestfield, S. Moore and W. H. Stein, J. Biol. Chem., 238, 622 (1963). 